\title{
Analysis of contamination of endodontic absorbent paper points
}

\author{
Análise da contaminação em cones endodônticos de \\ papel absorvente
}

\begin{abstract}
Purpose: The aim of this study was to assess the contamination status of endodontic absorbent paper points from sterilized or not sterilized commercial packs, as well as paper points exposed to the dental office environment.

Methods: Twenty absorbent paper points were evaluated for contamination status packed under different conditions: commercial/sterilized pack, commercial/non-sterilized pack, exposed to the clinical environment, and intentionally contaminated (positive control). Contamination was determined qualitatively and quantitatively by aerobiosis, capnophilic growth, and pour plate. The Petri dishes were analyzed with a colony counter, and the results were expressed as colony-forming units. The data were analyzed by Kruskal-Wallis test $(\alpha=0.05)$.

Results: No difference in colony-forming units was found among the groups of endodontic absorbent paper points. All groups were contaminated by fungi and bacteria.

Conclusion: It can be concluded that the sterilization of absorbent endodontic paper points before clinical use should be recommended regardless of commercial presentation
\end{abstract}

Key words: Contamination; endodontics; sterilization

\section{Resumo}

Objetivo: Este estudo avaliou a contaminação de cones de papel absorventes não esterilizados e esterilizados e selados em embalagens, e outros expostos ao ambiente de consultório odontológico.

Metodologia: Vinte cones de papel sob diferentes condições foram testados para verificar a contaminação: comercialmente esterilizados, comercialmente não esterilizados, expostos ao ambiente clínico, e intencionalmente contaminados. A contaminação foi determinada qualitativamente e quantativamente por diferentes condições: aerobiose, crescimento capnofílico ou pour plate. As placas Petri cultivadas com o cone foram analizadas através de contagem de colônias, e os resultados expressos em unidade formadora de colônias. Os dados foram analisados por teste de Kruskal-Wallis $(\alpha>0,05)$.

Resultados: Não houve diferença estatística significante entre os grupos, sendo que todos cones de papel endodôntico estavam contaminados por bactérias e fungos.

Conclusão: Concluiu-se que a esterilização de cones de papel endodônticos deve ser recomendada antes do uso clínico independente de sua apresentação comercial.

Palavras-chave: Contaminação; endodontia; esterilização

\author{
Érica Rodrigues Pereira a \\ Cleber Keiti Nabeshima b \\ Manoel Eduardo de Lima Machadoc \\ - Forças Armadas Hospital, Brasília, DF, Brazil \\ b Graduate Program, Department of Restorative \\ Dentistry, School of Dentistry, University of São \\ Paulo, São Paulo, SP, Brazil \\ c Department of Restorative Dentistry, School of \\ Dentistry, University of São Paulo, São Paulo, SP, \\ Brazil
}

\section{Correspondence:}

Manoel Eduardo de Lima Machado

Faculdade de Odontologia da USP

Av. Prof. Lineu Prestes, 2227 - Cidade Universitária

São Paulo, SP - Brazil

05508-000

E-mail: professormachado@hotmail.com

Received: October 25, 2010

Accepted: January 6, 2011

Conflict of Interest Statement: The authors state that there are no financial and personal conflicts of interest that could have inappropriately influenced their work.

Copyright: (C) 2011 Pereira et al.; licensee EDIPUCRS. This is an Open Access article distributed under the terms of the Creative Commons AttributionNoncommercial-No Derivative Works 3.0 Unported License. 


\section{Introduction}

The complexity of endodontic treatment should be carefully considered, because of the difficulties in avoiding contamination during chemical and surgical preparation up to the final moment of obturation. All endodontic procedures are aimed at creating and maintaining aseptic conditions and then obturation of the clean root canal (1).

Moisture inside the root canal system is a factor that directly influences the quality of sealing of the root canal $(2,3)$. Therefore, residual moisture from the irrigants of the chemical and surgical preparation should be removed, for which alcohols, aspiration cannula and cotton wicks have been proposed, but the most commonly utilized and effective are absorbent paper points $(3,4)$. In drying the root canal, four paper points are usually used, and other materials can be used, such as irrigating substances (alcohol), to minimize the possibility of residual moisture (4), as well reducing the number of absorbent points used (5). It has also been noted that paper points help remove residual superficial bacteria on the dentine wall, where the point thereby acts as a mechanical agent (6).

The presence of microorganisms is entirely linked to cases of failure in endodontic therapy, and many times this is due to failure in instrumentation, as well as bacterial infiltration through saliva or the use of contaminated instruments and/or materials $(7,8)$. Commercial paper points come in various quantities and shapes, even found packaged in small numbers and sterilized, which has been questioned (3). During their utilization, the remaining unused units can be contaminated (9), which is why many professionals should depend on re-sterilization of the points (10).

Therefore, the aim of this study was to analyze qualitatively and quantitatively the existence of contamination in sterilized absorbent paper points whether sealed or not in the commercial packs, as well as paper points exposed to the environment in the dental clinics.

\section{Methods}

Twenty absorbent paper points were utilized, varying in standard number and commercial brand, divided into five groups:

G1 - Negative control $(n=1)$, submitted to a sterilization cycle of $121^{\circ} \mathrm{C} / 15 \mathrm{~min}$

$\mathrm{G} 2$ - Point sealed and sterilized by the manufacturer $(\mathrm{n}=3)$

G3 - Point not sterilized by the manufacturer $(n=3)$

G4 - Point exposed to clinical environment $(n=10)$

G5 - Positive control $(n=3)$, intentionally contaminated by the mucosa of the patient.

After sterilization of the paper point in group 1, this specimen and the paper points of the other groups were identified, immersed in $5 \mathrm{~mL}$ sterile saline and incubated in a bacteriological incubator at $36^{\circ} \mathrm{C}$ for $24 \mathrm{~h}$. Afterwards, the points and saline were homogenized and submitted to the following tests (treatments):
- Treatment 1 - Capnophilic growth: A 1-mL aliquot of the point homogenate was pipetted into a tube with $5 \mathrm{~mL}$ of brain heart infusion broth (BHI, Biobrás, São Paulo, SP, Brazil) under microaerophilic conditions (candle method), and the tube then incubated in a bacteriological incubator at $36{ }^{\circ} \mathrm{C}$ for $3-5$ days.

- Treatment 2 -Aerobiosis: After the immersion of the point in saline for $24 \mathrm{~h}$, the suspension was homogenized and $1 \mathrm{~mL}$ was pipetted into a tube containing $5 \mathrm{~mL}$ of BHI broth, which was then incubated in bacteriological incubator at $36^{\circ} \mathrm{C}$ for $72 \mathrm{~h}$. After incubation, each sample in BHI broth was streaked on agar plates containing culture medium for Gram-negatives (CLED Agar, Difco, Rio de Janeiro, RJ, Brazil) and Gram-positives (Mannitol Salt Agar, Difco, Rio de Janeiro, RJ, Brazil), blood agar (Difco, Rio de Janeiro, RJ, Brazil) and medium for fungi (Agar Sabouraud - SS, Micromed, Porto Alegre, RS, Brazil).

The CLED, mannitol and blood agar plates were incubated in a bacteriological incubator at $36^{\circ} \mathrm{C}$ for $48 \mathrm{~h}$, and the Sabouraud plates were incubated at room temperature for 15 days for total growth of the viable organisms. After bacterial growth on agar plates with CLED and blood culture media, the different colonies were seeded in medium for the Rugai biochemical test with lysine, and bacterial growth on agar plates with mannitol culture medium was tested for catalase for the different cultures.

Catalase assay: The suspected colony was picked out and mixed with two drops of hydrogen peroxide (oxygenated water) on a glass slide. The assay was considered positive when there was the presence of catalase, demonstrated by the breakdown of hydrogen peroxide into free oxygen, producing gas bubbles.

- Treatment 3-Pour plate Bacteria: After immersion of the point in saline for $24 \mathrm{~h}$, the suspension was homogenized and $1 \mathrm{~mL}$ was pipetted into a Petri dish for seeding by the pour plate technique on standard PCA agar (Merck, São Paulo, SP, Brazil). After incubation, the Petri dishes were analyzed with a colony counter, and the results are expressed as colony-forming units (CFU).

- Treatment 4 - Pour plate Fungi: After immersion of the point in saline for $24 \mathrm{~h}$, the suspension was homogenized and $1 \mathrm{~mL}$ was pipetted into a Petri dish for seeding by the pour plate technique in standard Sabouraud agar.

After solidification of the medium, the plates were incubated at room temperature for 15 days. After incubation, the Petri dishes were analyzed with a colony counter, and the results were expressed as colony-forming units (CFU). The data were analyzed by Kruskal-Wallis statistical test at a level of significance of $5 \%$.

\section{Results}

Treatment 1 - capnophilic growth

The tubes incubated under microaerophilic conditions did not show turbidity after incubation, and examination of the culture on a microscope slide showed no bacterial growth under these conditions. 


\section{Treatment 2 - Aerobiosis}

Of the 20 samples incubated in BHI broth under aerobiosis, only two demonstrated turbidity, represented by the positive control. However, all samples replicated, demonstrated by the growth of colonies, where:

G1 - no type of bacteria or fungi were found;

G2 - equal amounts of Gram-positive and Gram-negative bacteria and fungi were found;

G3 - only fungi were found;

G4 - Gram-positive and Gram-negative bacteria and fungi were found, but the last two in greater amounts;

G5 - Gram-positive and Gram-negative bacteria and fungi were found.

The growth of the microorganisms for the groups is shown in Figure 1. Analysis of the growth of colonies demonstrated the presence of Proteus in G2 and G4, Serratia in G4 and G5, Staphylococcus aureus in G2 and G4, and Streptococcus mutans in G5.

\section{Treatment 3 - Pour plate bacteria}

Colony growth was seen in two samples of the positive control group in PCA culture medium and under conditions of incubation.

\section{Treatment 4 - Pour plate fungi}

Colony growth occurred in three samples, one in $\mathrm{G} 2$ with $3.65 \times 10^{2}$ CFU.mL-1 ${ }^{-1}$, one in G4 and one in G5, both with $4 \times 10^{1}$ CFU.mL ${ }^{-1}$.

Statistical analysis of the data indicated no difference between the groups (other than the negative control), where they were all contaminated by fungi and bacteria.

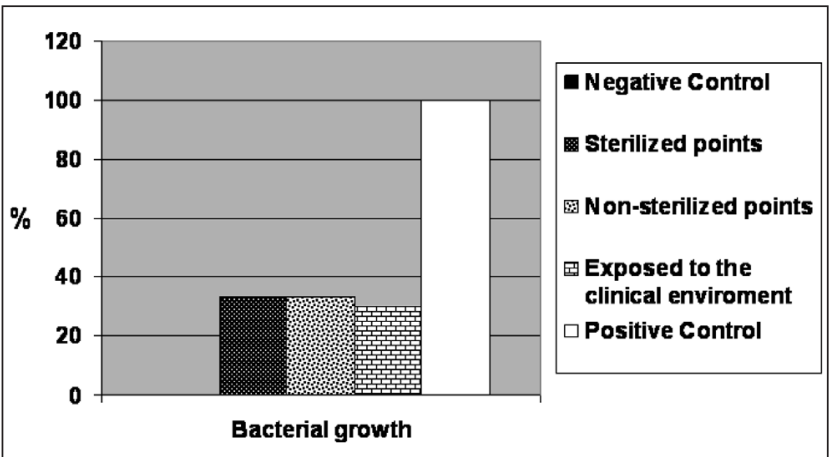

Fig. 1. Percent distribution of the growth of microorganisms among the groups of endodontic absorbent paper points.

\section{Discussion}

In the daily routine of the endodontic clinic, there is a preoccupation with keeping the environment clean, using aseptic materials to make the best efforts in removing undesirable microorganisms $(5,11)$. Therefore, we can find a gamut of materials sold for this purpose. Commercial absorbent paper points can be obtained from the manufacturer in sterile packages or not. Those that are not sterilized by the manufacturer can be subjected, each time the professional resorts to their use, to contamination by the environment or instruments or through lack of care in handling, which can influence the prognosis of the treatment.

The sterilization of these points should not compromise the initial physical, chemical and biological properties of the material. Thus, various studies have been conducted to examine such possible influences (12). Kuga et al. (1991) studied the influence of sterilization methods on the absorptivity of paper points, where there were no detectable chromatic alterations by visual analysis, but greater rigidity was apparent, suggesting that dehydration and/or carbonization of the fibers had occurred. Subsequent studies reported that both oven heating and autoclaving cause alterations that could affect the absorptive capacity of points, but it is an effective method for their sterilization $(3,10,13-15)$.

Through this study, we could determine the true situation with points encountered on the market as well as determining the probability of contamination that occurs in their handling. The verification of contamination did not take into consideration the brand, chemical composition, standardization pattern or taper, but whether their being exposed to an unfavorable clinical environment led to contamination or not.

The culture media utilized are those recommended in the literature as in the methods employed in previous bacteriological studies $(16,17)$. Based on the results obtained, the media inoculated with the samples all behaved similarly. The bacteria identified were Proteus, Serratia, Staphylococcus aureus, and Streptococcus mutans.

Proteus is a Gram-negative bacillus and facultative anaerobe of the enterobacteria group, considered an oral pathogenic microbe. It is commonly found in urinary tract infections, capable of causing nephritis and bacteremia, increasing risks of infection, mainly in renal transplant patients $(18,19)$. It has also been reported that Proteus is one of causes of sinusitis of odontogenic origin (20). Serratia is also a Gram-negative enterobacterial bacillus, but classified as a member of the Klebsiella division; it is primarily a nosocomial pathogen that causes bacteremia, meningitis and respiratory and urinary infections with high virulence potential, leading to antimicrobial resistance (21). Its presence has been reported in chronic suppurative apical periodontitis (22).

Unlike the aforementioned bacteria, Staphylococcus aureus is a Gram- positive coccus, which as a cluster appears as a yellow-colored bunch of grapes, and this bacterial species is frequently isolated from infected root canals (23). Streptococcus mutans is a facultative anaerobe, also a Gram-positive coccus, very commonly found in the oral cavity, which makes it the principal cause of caries due to its acidogenic and aciduric nature (24).

Contamination by fungi was debatable, because in this study we found that their growth requires a long period of time and because it is known that during drying the point 
is inside the canal for a very short time. Similarly, certain bacterial colonies need favorable media to develop, and even though many samples tended toward contamination, such as those of group 4, they did not develop. However, the internal anatomy of the root canal is very complex and there is still the possibility that such microorganisms would be responsible for infections resulting from apical lesions. However, the fact that no contamination occurred in the absence of oxygen, a situation similar to that of the root canal, makes us less apprehensive.

The results demonstrate that there was no statistically significant difference between the points of groups 2 ,
3 and 4, pointing out that greater quality control is needed in sterilization, not unusual as shown in previous studies, where sterile points were found to be contaminated $(3,9)$, corroborating the findings of the present study.

\section{Conclusions}

Based on the findings of this study, we conclude that to assure greater safety in endodontic procedures, the absorbent paper points should be autoclaved before clinical use, regardless of the commercial type.

2. Habitante SM, Bombana AC, Antoniazzi JH. Estudo comparativo in vitro da secagem do canal radicular de dentes humanos, variando-se o diâmetro das cânulas, o tempo de aspiração e associando-se ou não ao uso de cones de papel absorvente. Rev ABO Nac $1995 ; 3: 50-5$

3. Holland R, Nery MJ, Souza V, Mello W, Bernabé PFE, Filho JAO. Efeito da esterilização em estufa no poder de absorção dos cones de papel. Odontol Mod 1991;18:6-8.

4. Pécora JD, Silva RG, Vansan LP, Costa WF. Avaliação in vitro do número e do tempo de permanência de cones de papel absorvente, e a influencia da aspiração final, na secagem do canal radicular. Rev Odontol Univ São Paulo 1988;2:81-5.

5. Aguiar CM, Pinheiro JT. Influência de esterilização/desinfecção nos cones de papel absorventes. Rev Odontol Univ Sto Amaro 1998;3:54-8.

6. Engströem B. The significance of the number of absorbent paper points to positive endodontic cultures. Odontol Revy 1966;17:216-21.

7. Haapasalo M, Udnæs T, Endal U. Persistent, recurrent, and acquired infection of the root canal system post-treatment. Endod Topics 2003;6:29-56.

8. Nabeshima CK, Machado MEL, Britto MLB, Pallotta RC. Effectiveness of different chemical agents for disinfection of gutta-percha cones. Aust Endod J [1747-4477]. 2010 Ago [cited 2010 November 28]. Available at: http://onlinelibrary.wiley.com/doi/10.1111//.1747. 4477.2010.00256.x/full

9. Tartarotti E, Goldschmidt Al, Oliveira EPM, Kopper PMP, Faresin R. Avaliação microbiológica de pontas de papel absorvente e cones de guta-percha. Odontol Clin Científ 2004;3:103-9.

10. Kubo CH, Gomes APM, Jorge AOC. Efeitos da autoclavação na velocidade absorvente de cones de papel empregados em Endodontia. Rev Odontol Univ São Paulo 1999;13:383-9.

11. Kuga MC, Marcondes FN, Bertolini JC. Influência dos métodos de esterilização no poder de absorção dos cones de papel absorvente. Odont Mod 1991;18:10-4.

12. Victorino FR, Lukiantchuk M, Garcia LB, Bramante CM, Moraes IG, Hidalgo MM. Capacidade de absorção e toxicidade de cones de papel após esterilização. RGO 2008;56:41 1-5.

13. Bramante CM, Pontes HS, Bramante AS. Efeito dos métodos de esterilização e marcas sobre o poder de absorção dos cones de papel absorvente Rev FOB 1994;2:1 1-4.

14. Carvalho MGP, Duarte GCP, Amaral MM, Milano NF. Poder de absorção das pontas de papel: influência da esterilização em estufa a seco. Avaliação in vitro. RGO 1995;43:171-4.

15. Koppang HS, Koppang R, Solheim T, Aarnes H, Stolen SO. Cellulose fibers from endodontic paper points as an etiological factor in postendodontic periapical granulomas and cysts. J Endod 1989;15:369-72.

16. Santos LC. Laboratório Ambiental. Cascavel:EDUNIOESTE;1999.

17. Orstavik D, Möller B. Bacteriological studies on endodontic paper points. Acta Odontol Scand 1985;43:91-5.

18. Costa Filho JZ, Padilha WSM, Santos EKN. Cuidados odontológicos em portadores de insuficiência renal crônica. Rev Cir Traumatol Buco-Maxilo-Fac 2007;7:19-27.

19. Pellegrino R, Galvalisi U, Scavone P, Sosa V, Zunino P. Evaluation of Proteus mirabilis structural fimbrial proteins as antigens against urinary tract infections. FEMS Immunol Med Microbiol 2003;36:103-10. 
20. Dinatale Papa E. Diseminación de la infección odontogénica - revisión de la literatura. Acta odontol Venez 2000;38:37-43.

21. Carbonell GV, Fonseca BAL, Figueiredo LTM, Darini ALC, Yanaguita RM. Culture conditions affect cytotoxin production by Serratia marcescens. FEMS Immunol Med Microbiol 1996; 16:399-07.

22. Becerra Rojas MM, Garzón Prieto OR, Reyna Duarte MB, Mayorga de Fayad I, Lancheros Bonilla S, Polo Rodríguez JT et al. Presencia de microorganismos productores de b-lactamasa en dientes de pacientes con periodontitis apical crónica supurativa. Rev Fed Odontol Colomb 2005;25:15-22.

23. Zebral AA, Ether SS. Classificação e prevalência dos grupos microbianos encontrados em canais radiculares infectados. Odonto Mod 1984;1 1:14-24.

24. Leites ACBR, Pinto MB, Sousa ER. Aspectos microbiológicos da cárie dental. Salusvita 2006;25:135-48. 